\title{
Komunitas Bakteri pada Saluran Pencernaan Lobster Mutiara (Panulirus ornatus)
}

\author{
Bacteria Community in the Gastrointestinal Tract of Pearl Lobster \\ (Panulirus ornatus) \\ Arba'i Kartini Nurhasanah dan Faturrahman* \\ ${ }^{1}$ Program Studi Biologi, Fakultas Matematika dan Ilmu Pengetahuan Alam, \\ Universitas Mataram, \\ Jl. Majapahit 62 Mataram 83125, Telp.(0370) 646506 INDONESIA \\ *corresponding author, email: fatur@unram.ac.id
}

Manuscript received: 16-04-2019. Accepted: 15-05-2019

\begin{abstract}
ABSTRAK
Keberadaan komunitas mikroba pada saluran pencernaan berpengaruh terhadap fungsi fisiologis pencernaan. Tujuan penelitian ini untuk mengetahui komunitas bakteri pada saluran pencernaan lobster khususnya lobster mutiara. Penelitian ini bersifat deskriptif eksploratif. Sampel diambil dari saluran pencernaan lobster yang dibagi 3 yaitu bagian kardiak, pylorus dan usus, dan masing-masing bagian dihitung total bakterinya menggunakan metode TPC (Total Plate Count). Kemudian diisolasi pada media Sea Water Complex dan dikarakterisasi secara parsial. Hasil penelitian menunjukkan bahwa

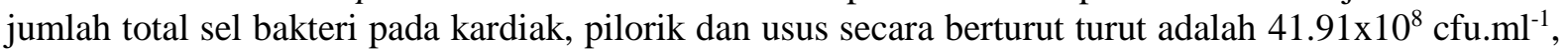
$18.26 \times 10^{8} \mathrm{cfu}^{-\mathrm{ml}^{-1}}$ dan $14.10 \times 10^{8} \mathrm{cfu} \cdot \mathrm{ml}^{-1}$. Jumlah isolat bakteri yang diperoleh dari saluran pencernaan lobster mutiara sebanyak 51 isolat dengan rincian 18 isolat pada kardiak, 16 isolat pada pilorik, dan 17 isolat pada usus. Fenotipik isolat bakteri saluran pencernaan lobster yang didapat terdiri dari bentuk monococcus $37.25 \%$, diplococcus $27.45 \%$, streptococcus $29.41 \%$, staphylococcus $1.96 \%$, dan basil panjang $3.92 \%$, sedangkan gram positif sebesar $62.75 \%$ dan gram negatif sebesar $37.25 \%$.
\end{abstract}

Kata kunci: keragaman; mikroba; udang barong; fungsi fisiologis pencernaan

\section{ABSTRACT}

The presence of microbial communities in the digestive tract affects the physiological functions of digestion. The purpose of this study is to determine the bacterial community in the digestive tract of lobsters, especially pearl lobsters. This research is descriptive explorative. Samples were taken from the lobster digestive tract which was divided into 3, namely the cardiac, pylorus and intestinal sections and each part was counted for the total bacteria using the TPC (Total Plate Count) method. Then isolated from the Sea Water Complex media and partially characterized. The results showed that the total number of bacterial cells in cardiac, piloric and intestinal cells were $41.91 \times 10^{8} \mathrm{cfu}^{-\mathrm{ml}^{-1}}, 18.26 \times 10^{8}$ cfu. $\mathrm{ml}^{-1}$ and $14.10 \times 10^{8} \mathrm{cfu} . \mathrm{ml}^{-1}$ respectively. The number of bacterial isolates obtained from the lobster 
pearl digestive tract were 51 isolates with details of 18 cardiac isolates, 16 isolates in piloric, and 17 isolates in the intestine. Phenotypic isolates obtained from lobster digestive tract bacteria consisted of monococcus $37.25 \%$, diplococcus $27.45 \%$, streptococcus $29.41 \%$, staphylococcus $1.96 \%$, and long baccil $3.92 \%$, while gram positive $62.65 \%$ and gram negative at $37.25 \%$.

Keyword: biodiversity; microba; spiny lobster; digestion, physiologis

\section{PENDAHULUAN}

Lobster merupakan salah satu komoditas laut yang sangat diminati oleh masyarakat dan menjadi komoditas ekspor yang berkembang saat ini. Permintaan lobster tiap tahunnya selalu meningkat tidak hanya di dalam negeri tapi juga di luar negeri dibuktikan dengan data ekspor Indonesia ke berbagai negara (Dradjat, 2004). Ekspor Indonesia ke Amerika Serikat pada tahun 1988 mencapai 174 ton sedangkan ekspor ke Jepang mencapai 139 ton (Boesono et al. 2011). Pada tahun 1990, ekspor lobster ke Belanda, mencapai 745,132 ton atau 89,59\% dari total ekspor lobster Indonesia (826 ton) Pada tahun 1995, ekspor lobster Indonesia mencapai 182.065 ton setiap tahun tahun, $2 \%$ dari total ekspor (3.641,3 ton) diantaranya adalah lobster. Total ekspor hasil lobster budidaya mencapai 94.511 ton setiap tahun (Priyono, 2009). Salah satu jenis lobster yang paling diminati adalah lobster mutiara (Panulirus ornatus). Lobster ini merupakan lobster air laut yang di budidaya pada keramba.

Permintaan konsumen yang terus meningkat tidak diiringi oleh kecepatan pertumbuhan lobster sehingga menyebabkan kesulitan untuk memenuhi pasokan permintaan konsumen. Pembesaran lobster mutiara dari benih sampai menjadi dewasa membutuhkan waktu sekitar 89 bulan (Suastika et al. 2008). Hal ini berkaitan dengan sistem percernaan pada lobster, terutama komponen mikroba yang terdapat pada saluran cerna lobster. Aktivitas dan kapasitas metabolik yang sangat beragam dari mikroba inilah yang dapat memberi pengaruh positif maupun negatif pada fungsi fisiologis saluran pencernaan. Aktivitas metabolik sistem pencernaan sangat penting dalam menghasilkan energi, dan hanya sekitar 25\% saja digunakan untuk proses pencernaan dan penyerapan makanan itu sendiri (Saputra, 2010). Brooks et al. (1996) mengemukakan bahwa mikroflora asli saluran pencernaan mempunyai hubungan mutualisme dengan inangnya, yaitu memanfaatkan inang sebagai tempat hidupnya. Keuntungan bagi inang adalah umumnya mikroba memakan sisa atau menggunakan bahan buangan, banyak bakteri usus dapat mensintesis vitamin, mensekresi enzim, membantu pencernaan nutrien, dan kehadiran mikroba asli cenderung menekan pertumbuhan bakteri patogen sehingga dapat melindungi inang terhadap penyakit serta merangsang fungsi kekebalan tubuh.

Melihat pentingnya fungsi mikroba pada saluran pencernaan bagi pertumbuhan maka diperlukan pengetahuan tentang jenis mikroba pada sistem pencernaan lobster untuk mengetahui kemampuan cerna lobster. Sehingga ke depannya dapat dimanfaatkan untuk pengembangan komposisi produksi pakan yang dapat meningkatkan pertumbuhan lobster mutiara. Penelitian ini bertujuan untuk mendapatkan data tentang jumlah mikroba dan kelompok mikroba yang berada pada saluran pencernaan lobster mutiara (Panulirus ornatus). 


\section{MATERI DAN METODE}

\section{Pengambilan Sampel Lobster}

Sebanyak 10 ekor lobster mutiara ukuran 350 gram diperoleh dari hasil budidaya Balai Budidaya Laut Lombok Stasiun Gerupuk. Sampel lalu dimasukkan dalam ice box yang berisi es batu. Selanjutnya sampel di bawa ke Laboratorium Biologi FMIPA Universitas Mataram untuk diteliti.

\section{Pembuatan Media Pertumbuhan Bakteri}

Pembuatan media SWC (seawater complex) yang terdiri dari $5 \mathrm{~g}$ bactopeptone, $1 \mathrm{~g}$ yeast extract, $3 \mathrm{ml}$ glycerol, $15 \mathrm{~g}$ agar, $750 \mathrm{ml}$ air laut, dan $250 \mathrm{ml}$ aquades (Widanarni et al. 2004) Setelah itu dipanaskan diatas hot plate dan diaduk rata menggunakan magnetic stirrer. Media disterilisasi menggunakan autoklaf pada suhu $121{ }^{\circ} \mathrm{C}$ tekanan $2 \mathrm{~atm}$ selama 20 menit. Selanjutnya dalam keadaan hangat $\left(50{ }^{\circ} \mathrm{C}\right)$, media dituang ke cawan steril dan dibiarkan memadat. Media ini merupakan jenis media umum yang digunakan untuk organisme akuatik dan bertujuan untuk memaksimalkan pertumbuhan kelompok bakteri

\section{Pengambilan Isi Saluran Pencernaan Lobster}

Pengambilan isi saluran pencernaan lobster mutiara sebagai sumber inokulum dilakukan dengan melakukan pembedahan. Bakteri dari usus diambil dengan cara mengeluarkan organ pencernaan lobster mutiara yang sudah mencapai fase dewasa menggunakan sectio. Organ percernaan dipisah menjadi 3 yaitu bagian kardiak, pylorus dan usus dan ditempatkan di 3 tempat yang berbeda. Masing-masing bagian dari organ pencernaan (kardiak, pylorus dan intestinum) ini kemudian digerus menggunakan mortar lalu ditimbang sebanyak $1 \mathrm{~g}$ menggunakan timbangan analitik.

\section{Pengenceran Sampel}

Satu gram homogenat saluran pencernaan disuspensikan ke dalam $9 \mathrm{~mL}$ air laut streril dan dihomogenkan menggunakan vortex, sehingga terbentuk seri pengenceran $10^{-1} \mathrm{cfu}_{\mathrm{ml}}{ }^{-1}$. Larutan stok dengan pengenceran $10^{-1} \mathrm{cfu} \cdot \mathrm{ml}^{-1}$ tersebut, dicuplik sebanyak $1 \mathrm{~mL}$ dan dilarutkan kedalam $\mathrm{NaCl} 0,9 \%$ membentuk larutan dengan seri pengenceran $10^{-2} \mathrm{cfu}^{\mathrm{ml}} \mathrm{m}^{-1}$. Larutan tersebut kemudian dihomogenisasi menggunakan vortex. Prosedur yang sama dilakukan untuk membuat seri pengenceran selanjutnya sampai pengenceran $10^{-8} \mathrm{cfu}^{\mathrm{ml}}{ }^{-1}$. Kemudian diinkubasi selama 48 jam pada suhu $35^{\circ} \mathrm{C}$ (Subagiyo dan Ali, 2011)

\section{Inokulasi Bakteri}

Larutan dengan seri pengenceran $10^{-5} \mathrm{cfu}^{-\mathrm{ml}^{-1}}, 10^{-6} \mathrm{cfu}^{\mathrm{ml}}{ }^{-1}, 10^{-7} \mathrm{cfu}^{\mathrm{ml}} \mathrm{l}^{-1}$ dan $10^{-8}$ cfu. $\mathrm{ml}^{-1}$ masing-masing diambil sebanyak $5 \mu 1$ menggunakan mikropipet, kemudian ditanam pada media Sea Water Complex dengan teknik sebar menggunakan spreader. Semua biakan diinkubasi pada suhu $30{ }^{\circ} \mathrm{C}$ selama 18-24 jam. 


\section{Perhitungan Total Bakteri}

Penghitungan Total Bakteri menggunakan metode Total Plate Count (TPC) yang merupakan metode pendugaan jumlah mikroorganisme secara keseluruhan dari suatu bahan (Zaki, 2011). Hasil hitung koloni berupa (cfu) per ml. Perhitungan koloni dilakukan pada seri pengenceran

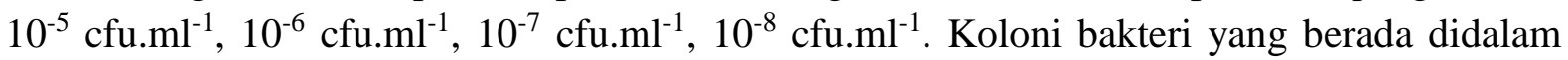
cawan petri diletakkan ke dalam kamar hitungcolony counter, kemudian diatur pada posisi nol dan koloni mulai dihitung dengan menggunakan jarum penunjuk sambil melihat jumlah pada layar hitung. Menurut Nababan (2008) dan Sari et al. (2013), kepadatan sel bakteri dapat dihitung dengan cara:

$$
\text { Jumlah koloni } \mathrm{x} \frac{1}{\text { pengenceran }}\left(\text { cfu.ml }^{-1}\right)
$$

Analisis disajikan dalam suatu Standards Plate Counts (SPC) dan dalam bentuk tabeluntuk mempermudah dalam pembacaan. SPC merupakan metode untuk mendapatkan hasil jumlah mikroba dengan range 30 - 300 CFU (Colony Forming Unit) per ml (Yunita et al. 2015).

\section{Isolasi dan Pemurnian Bakteri}

Isolasi bakteri saluran pencernaan dilakukan dengan mengamatikoloni bakteri yang tumbuh pada media Sea Water Complex dengan cara melihat karakter morfologi koloni yang meliputi warna, tepian, elevasi, dan bentuk atas koloni yang memiliki karakter morfologi berbeda kemudian diberi kode berbeda. Masing-masing koloni yang memiliki kode berbeda dimurnikan dengan cara menggoreskan sebanyak satu ose koloni bakteri pada media Sea Water Complex di cawan petri kemudian diinkubasi pada suhu $28^{\circ} \mathrm{C}$ selama 24 jam. Pemurnian dilakukan berulang-ulang hingga diperoleh pertumbuhan koloni yang terpisah.

\section{Pengamatan Morfologi Koloni}

Pengamatan morfologi koloni dilakukan dengan cara melihat bentuk, elevasi, tepian dan warna koloni yang tumbuh pada media Sea Water Complex.

\section{Uji Motilitas}

Sebanyak 1 ose isolat bakteri diambil dan dipindahkan ke dalam tabung reaksi berisi 5 $\mathrm{ml}$ media Nutrien Broth cair dan diinkubasi selama 16-24 jam pada suhu $28{ }^{\circ} \mathrm{C}$. Setelah itu diamati motilitas bakteri dengan menggunakan mikroskop.

\section{Pengamatan Morfologi Sel}

Pengamatan morfologi sel dilakukan dengan pewarnaan gram. Koloni bakteri diambil dari media sebanyak satu ose secara aseptik dan diletakkan di atas tetesan aquades pada kaca objek. Kemudian dibuat preparat hapusan secara merata dan dikeringkan di atas api bunsen. Preparat ditetesi Reagen A (kristal violet), didiamkan selama 60 detik, lalu dicuci di bawah air mengalir. Setelah itu ditambahkan Reagen B (lugol iodine) didiamkan selama 120 detik, lalu dicuci di bawah air mengalir. Preparat didecolorisasi dengan Reagen C (alkohol 96\%) selama 
30 detik dan dibilas dengan air mengalir. Setelah itu ditetesi Reagen D (safranin) didiamkan selama 30 detik dan dibilas dengan air mengalir. Preparat dikeringkan dan di atasnya diberi satu tetes minyak imersi untuk menghindarkan perbedaan indeks bias. Preparat diamati di bawah mikroskop dengan perbesaran 1000x. Hasil pengamatan dicatat dan didokumentasikan. Bakteri gram negatif berwarna merah dan bakteri gram positif berwarna ungu (Hadioetomo, 2003).

\section{HASIL DAN PEMBAHASAN}

\section{Total Bakteri Saluran Pencernaan Lobster}

Total Plate Count (TPC) merupakan metode yang paling banyak digunakan dalam analisa jumlah total bakteri, karena koloni dapat dilihat langsung dengan mata tanpa menggunakan mikroskop. Hasil perhitungan jumlah sel bakteri dari saluran pencernaan lobster pada media TPC Agar disajikan pada Tabel 1.

Tabel 1. Angka Lempeng Total Bakteri pada Saluran Pencernaan Lobster Mutiara

\begin{tabular}{lc}
\hline Lokasi & Media Sea Water Complex \\
\hline Kardiak & $41.91 \times 10^{8} \mathrm{cfu}^{-1} \mathrm{~m}^{-1}$ \\
Pilorik & $18.26 \times 10^{8} \mathrm{cfu} \cdot \mathrm{ml}^{-1}$ \\
Usus & $14.10 \times 10^{8} \mathrm{cfu} \cdot \mathrm{ml}^{-1}$ \\
\hline
\end{tabular}

Keterangan: $\mathrm{cfu}^{\mathrm{ml}} \mathrm{l}^{-1}=$ colony forming unit per $\mathrm{ml}$

Koloni yang tumbuh berupa koloni yang tersebar pada media dankoloni yang menyebar merata dihitung 1 koloni. Perbedaan angka lempeng total bakteri pada tiap segmen saluran percernaan lobster disebabkan oleh fungsi fisiologis dari tiap segmen saluran pencernaan. Angka lempeng total bakteri paling tinggi terdapat pada kardiak, yaitu $41.91 \times 10^{8} \mathrm{cfu}^{\mathrm{m}} \mathrm{ml}^{-1}$, diiikuti oleh segmen pilorik $18.26 \times 10^{8} \mathrm{cfu} \cdot \mathrm{ml}^{-1}$ dan yang terakhir yang paling rendah ada pada usus dengan angka lempeng total $14.10 \times 10^{8} \mathrm{cfu}^{-\mathrm{ml}^{-1}}$. Tiap segmen saluran pencernaan ikan memiliki fungsi yang berbeda-beda (Affandi et al. 2005, Aslamiyah et al. 2009), sehingga berpengaruh terhadap jumlah dan jenis mikroba yang mendiami segmen tersebut.

Jumlah bakteri pada segmen kardiak paling tinggi bila dibandingkan dengan segmen lain karena pada kardiak terjadi percernaan fisik dan enzimatik sehingga diduga mikroba yang ada pada kardiak memiliki peran penting dalam membantu pencernaan pada segmen kardiak. Kemudian angka lempeng total kedua terbanyak yaitu pada segmen pilorik. Pilorik berperan dalam mencerna makanan yang berasal dari kardiak dan diduga dibantu oleh mikroba yang ada pada segmen pilorik, namun pilorik lebih berperan sebagai tempat penyortir suspensi makanan dari kardiak menuju usus. Sedangkan usus merupakan tempat penyerapan makanan yang berasal dari pilorik.Jumlahdan persentase isolat pada tiap segmen saluran pencernaan lobster mutiara pada Tabel 2.

Bakteri pada saluran pencernaan udang lobster dapat tumbuh dengan baik pada Media SWC. Salah satu faktor yang mempengaruhi pertumbuhan bakteri pada media adalah nutrisi. Media digunakan untuk menumbuhkan bakteri yang berisi berbagai macam nutrisi yang dibutuhkan oleh bakteri untuk tumbuh. Zat makanan yang dibutuhkan bakteri pada umumnya sangat bervariasi, dapat berbentuk senyawa-senyawa organik sederhana atau senyawa-senyawa 
organik komplek (majemuk), yaitu berupa ekstrak ragi, sari protein atau zat-zat sejenis (Madigan et al. 2009). Pepton berfungsi sebagai sumber/persediaan nitrogen bagi pertumbuhan bakteri, mudah larut dalam air, tidak rusak/menggumpal pada suhu tinggi dan juga berfungsi sebagai buffer (penyangga) (Hidayat dan Sutarma, 1999). Selain itu, salah satu zat makan an yang dapat memberi energi yang tinggi yaitu lemak yang dapat dipecah menjadi glyserol dan asam lemak (Campbell et al. 2008). Media Sea Water Complex merupakan media yang umum dipakai untuk menumbuhkan bakteri yang berasal dari hewan akuatik.

Tabel 2. Jumlah dan persentase isolat pada tiap segmen saluran pencernaan lobster mutiara

\begin{tabular}{lcc}
\hline \multirow{2}{*}{ Lokasi } & \multicolumn{2}{c}{ Media Sea Water Complex } \\
\cline { 2 - 3 } & $\sum$ & \% \\
\hline Kardiak & 18 & $35.29 \%$ \\
Pilorik & 16 & $31.38 \%$ \\
Usus & 17 & $33.33 \%$ \\
\hline
\end{tabular}

Selain nutrisi, faktor lain yang mempengaruhi pertumbuhan bakteri yaitu suhu. Setiap spesies bakteri tumbuh pada kisaran suhu tertentu. Bakteri psikrofil mampu tumbuh pada suhu minimum $0-5^{\circ} \mathrm{C}$, optimum $5-15^{\circ} \mathrm{C}$, dan maksimum $15-20^{\circ} \mathrm{C}$. Bakteri mesofil dapat tumbuh pada suhu minimum $10-20^{\circ} \mathrm{C}$, optimum $20-40^{\circ} \mathrm{C}$ dan maksimum $40-45^{\circ} \mathrm{C}$. Bakteri dapat tumbuh pada suhu minimum $25-45^{\circ} \mathrm{C}$, optimum $45-60^{\circ} \mathrm{C}$ dan maksimum $60-80^{\circ} \mathrm{C}$ disebut dengan bakteri termofil (Madigan et al. 2009, Brooks et al. 1996). Bakteri pada saluran pencernaan merupakan kelompok bakteri mesofil.

Hasil pengamatan warna koloni didominasi oleh warna putih (11 isolat), diikuti oleh warna putih susu ( 9 isolat), kuning ( 6 isolat), bening (4 isolat), kuning bening ( 4 isolat), putih membentuk zona bening ( 3 isolat), putih kehijauan ( 3 isolat), putih bening ( 3 isolat), putih kekuningan ( 2 isolat), putih bening ditengah kuning ( 1 isolat), kuning bening membentuk zona bening ( 1 isolat), bening ditengah kuning ( 1 isolat), dan putih ditengah bening ( 1 isolat). Warna yang terbentuk pada koloni berasal dari pigmen warna. Menurut Safrida et al (2012) bahwa pigmen yang terdapat pada bakteri dintaranya adalah pigmen karotenoid, antosianin, melanin, Tripirilmethene dan Phenazin. Masing-masing dari pigmen tersebut akan memberikan warna yang berbeda-beda. Melanin memberikan warna coklat, hitam dan jingga. Tripirilmethenes adalah pigmen yang dihasilkan oleh Serratia marcescens dan phenazin memberikan warna jingga kuning, jingga tua dan merah jingga, sedangkan warna merah, kuning dan oranye pada isolat disebabkan adanya karatenoid (Sahara et al, 2013; Arlita et al, 2013).

Bentuk koloni didominasi oleh bulat (26 isolat), kemudian diikuti oleh bentuk tidak beraturan (18 isolat), agak lonjong (5 isolat), berserabut ( 1 isolat) dan bulat memanjang (1 isolat). Ukuran koloni pada didominasi oleh kecil (37 isolat) dan ukuran besar (14 isolat). Tepian koloni didominasi oleh tepian tidak rata (22 isolat), diikuti oleh tepian rata (21 isolat), bergelombang ( 5 isolat), dan berserabut ( 3 isolat). Elevasi koloni didominasi rata (29 isolat), kemudian cembung (19 isolat) dan tidak rata (2 isolat).

Bakteri yang ditemukan pada penelitian ini yaitu terdiri dari beberapa bentuk yakni coccus yang berupa bentuk monococccus $37.25 \%$, streptococcus $29.41 \%$, diplococcus $27.45 \%$, 
basil panjang 3.92\% dan staphylococcus $1.96 \%$. Selain bentuk, diamati pula warna gram pada bakteri yaitu bakteri gram positif yang berwarna ungu sebesar $62.75 \%$ dan bakteri gram negatif yang berwarna merahsebesar 37.25\%. Distribusi Morfologi Sel pada Media Sea Water Complex disajikan pada Tabel 3.

Tabel 3. Distribusi Morfologi Sel pada Media Sea Water Complex

\begin{tabular}{|c|c|c|c|c|c|c|c|c|c|c|c|c|c|}
\hline \multirow{3}{*}{$\begin{array}{c}\text { Bentuk } \\
\text { Sel }\end{array}$} & \multirow{3}{*}{$\begin{array}{l}\text { Total } \\
\left(\sum\right)\end{array}$} & \multicolumn{4}{|c|}{ Kardiak } & \multicolumn{4}{|c|}{ Pilorik } & \multicolumn{4}{|c|}{ Usus } \\
\hline & & \multicolumn{2}{|c|}{$\begin{array}{c}\text { Gram } \\
\text { Positif }\end{array}$} & \multicolumn{2}{|c|}{$\begin{array}{c}\text { Gram } \\
\text { Negatif }\end{array}$} & \multicolumn{2}{|c|}{$\begin{array}{l}\text { Gram } \\
\text { Positif }\end{array}$} & \multicolumn{2}{|c|}{$\begin{array}{c}\text { Gram } \\
\text { Negatif }\end{array}$} & \multicolumn{2}{|c|}{$\begin{array}{c}\text { Gram } \\
\text { Positif }\end{array}$} & \multicolumn{2}{|c|}{$\begin{array}{c}\text { Gram } \\
\text { Negatif }\end{array}$} \\
\hline & & $\sum$ & $\%$ & $\sum$ & $\%$ & $\sum$ & $\%$ & $\sum$ & $\%$ & $\sum$ & $\%$ & $\sum$ & $\%$ \\
\hline Monococcus & 19 & 6 & 31.58 & 1 & 5.26 & 2 & 10.53 & 4 & 21.05 & 4 & 21.05 & 2 & 10.53 \\
\hline Diplococcus & 14 & 5 & 35.71 & - & - & 1 & 7.14 & 3 & 21.43 & 1 & 7.14 & 4 & 28.57 \\
\hline Streptococcus & 15 & 2 & 13.33 & 2 & 13.33 & 5 & 33.33 & 1 & 6.67 & 3 & 20.00 & 1 & 13.33 \\
\hline Staphylococcus & 1 & - & - & - & - & - & - & - & - & 1 & 100 & - & - \\
\hline Basil panjang & 2 & 2 & 100 & - & - & - & - & - & - & - & & - & - \\
\hline
\end{tabular}

Prinsip pewarnaan gram yaitu kemampuan dinding sel dalam mengikat zat warna dasar (kristal violet) setelah pencucian dengan alkohol 95\%. Bakteri yang tetap berwarna seperti kristal violet setelah pewarnaan gram disebut bakteri gram positif sedangkan bakteri yang melepaskan kristal violet dan mengikat safranin sehingga berwarna merah atau merah muda disebut bakteri gram negatif (Pratita dan Surya, 2012). Keadaan ini berhubungan dengan komposisi senyawa penyusun dinding sel. Pada bakteri gram positif mengandung peptidoglikan lebih banyak dan lemak lebih sedikit dibandingkan bakteri gram negatif (Sari et al. 2013).

Bakteri gram positif merupakan bakteri yang memiliki dinding sel cukup tebal (20$80 \mathrm{~mm}$ ) dan terdiri atas $60 \%$ sampai $100 \%$ peptidoglikan yaitu polimer $N$-asetil glukosamin dan asam $N$-asetil muramat + beberapa asam amino yang menyusun dinding sel yang kaku pada organisme prokariota, sedangkan bakteri gram negatif merupakan bakteri yang memiliki dinding sel dengan peptidoglikan lebih sedikit dari bakteri gram positif, yaitu hanya sekitar $10 \%$ sampai $20 \%$ bobot kering dinding selnya, akan tetapi di luar lapisan peptidoglikan terdapat struktur membran ke dua yang tersusun dari protein fosfolipida (komposisi lipid spesifik dari membran sel) dan lipopolisakarida (asam lemak yang dirangkai dengan polisakarida) (Adji, 2008).

Sebagian besar bakteri yang ditemukan pada saluran pencernaan lobster mutiara didominasi oleh bakteri berbentuk coccus, hanya sedikit yang berbentuk basil. Sebagian besar bersifat motil dan hanya sedikit yang bersifat nonmotil. Sifat motil ini disebabkan karena adanya flagel yang membantu pergerakan bakteri (Madigan et al. 2009). Sifat motilitas pada bakteri probiotik penting karena berhubungan dengan kemampuan bakteri untuk mencapai lokasi situs target pada sel epitel usus, menempel serta berkolonisasi pada situs target.

Isolat bakteri yang diperoleh dari saluran pencernaan lobster mutiara ini berpotensi sebagai kandidat probiotik pemicu pertumbuhan lobster. Diantara persyaratan suatu strain bakteri dapat digunakan sebagai probiotik akuakultur untuk tujuan mempercepat pertumbuhan organisme inang adalah kemampunnya untuk mampu hidup (viable) pada berbagai kondisi lingkungan perairan (Faturrahman dan Widiyanti, 2012), tidak pathogen dan tidak resisten 
terhadap antibiotik (Faturrahman, 2013), serta mampu menghasilkan enzim-enzim pencernaan (Faturrahman et al. 2015).

\section{KESIMPULAN}

Jumlah mikroba yang berada pada saluran pencernaan lobster mutiara (Panulirus ornatus) yaitu pada kardiak $41.91 \times 10^{8} \mathrm{cfu} / \mathrm{ml}$, pilorik $18.26 \times 10^{8} \mathrm{cfu} / \mathrm{ml}$ dan usus $14.10 \times 10^{8}$ cfu/ml.Bakteri yang tumbuh pada media Sea Water Complex, bentuk monococccus berjumlah $37.25 \%$, streptococcus $29.41 \%$, diplococcus $27.45 \%$, basil panjang $3.92 \%$ dan staphylococcus $1.96 \%$, jumlah bakteri gram positif sebesar $62.75 \%$ dan bakteri gram negatif sebesar $37.25 \%$. Perlu diadakan penelitian lebih lanjut mengenai karakterisasi bakteri yang ada pada saluran pencernaan lobster mutiara (Panulirus ornatus).

\section{DAFTAR PUSTAKA}

Adji, K. 2008. Evaluasi Kontaminasi Bakteri Pathogen pada Ikan Segar di Perairan teluk Semarang. Semarang: Program Pascasarjana Universitas Diponegoro [Tesis].

Affandi R, D.S. Sjafei, M.F. Raharjo, dan Sulistiono. 2005. Fisiologi ikan-pencernaan dan penyerapan makanan. Departemen MSP, FPIK IPB

Arlita, N.R., K.R. Ocky, dan S. Adi. 2013. Identifikasi Pigmen Karotenoid Pada Bakteri Simbion Rumput Laut Caulerpa cupressoides (Vahl) C.Agardh. Journal of Marine Research, Vol. 2, No.3.

Aslamiyah, S., H.Y. Azis, Sriwulan, dan K.G. Wiryawan. 2009. Mikroflora Saluran Pencernaan Ikan Gurame (Osphronemus gouramy Lacepede). Jurnnal Ilmu Kelautan dan Perikanan. Vol.19, No.1.

Boesono, H., A. Sutrisno, dan N.B. Aziz. 2011. Laju Tangkap dan Analisis Usaha Penangkapan Lobster (Panulirus sp.) dengan Jaring Lobster (Gillnet Monofilament) di Perairan Kabupaten Kebumen. Jurnal Saintek Perikanan, Vol.7, No.1

Brooks, G.F., S.B. Janet dan O. Nicholas. 1996. Mikrobiologi Kedokteran. Jakarta: EGC.

Campbell, N. A., Jane B.R., Lisa A.U., Michael L. C., Steven A. W., Peter V. M., Robert B. J. 2008. Biologi Edisi Kedelapan Jilid 1. Jakarta: Erlangga.

Dradjat, F. M. 2004. Bioekonomi Udang Karang (Panulirus spp.) pada Usaha Perikanan Tangkap Skala Kecil di Kabupaten Kebumen dan Sekitarnya. Semarang: Program Pasca Sarjana Universitas Dipponegoro [Tesis].

Faturrahman dan L. Widiyanti. 2012. Seleksi Parsial Vibrio Spp. Kandidat Probiotik: Viabilitas pada Berbagai Kondisi Suhu, pH dan Salinitas. Jurnal Biologi Vol. 16 No. 2 Faturrahman. 2013. Seleksi Parsial Probiotik untuk Pertumbuhan Abalon: Isolasi Selektif, Resistensi Antibiotik dan Patogensitas. Jurnal Biologi Edukasi. Vol 5, No. 1

Faturrahman, A. Meryandini, M.Z. Junior dan I. Rusmana. 2015. The Role of Agarolytic Bacteria in Enhancing Physiological Function for Digestive System of Abalone (Haliotis asinina). Journal Applied Environmental and Biological Science. Vol. 5 No. 5

Hadioetomo, R. S. 2003. Mikrobiologi Dasar dalam Praktek. Jakarta: PT. Gramedia Pustaka Utama. 
Hidayat, Y dan Sutarma. 1999. Teknik Pembuatan Kultur Media Bakteri. Bogor: Lokakarya Fungsional Non Peneliti.

Madigan M.T., J.M. Martinko, P.V. Dunlap, dan D.P. Clark. 2009. Brock Biology of Microorganisms. Edisi 12. Pearson Benjamin Cummings, San Francisco

Nababan, B. 2008. Isolasi dan Uji Potensi Bakteri Pendegradasi Minyak Solar dari Laut Belawan. Medan: Universitas Sumatera Utara [Thesis].

Pratita, M.Y. dan E.,Surya R.P. 2012. Isolasi dan Identifikasi Bakteri Termofilik dari Sumber Mata Air Panas di Songgoriti Setelah Dua Hari Inkubasi. Jurnal Teknik Pomits, vol.1, No. 1

Priyono, E. 2009. Alternatif Penambahan Suplemen Hayati untuk Meningkatkan Pertumbuhan Udang Lobster Air Tawar (Cherax quadricarinatus). Surakarta: Program Pasca Sarjana Universitas Sebelas Maret [Tesis].

Safrida, Y.D., Y.Cut, dan N.D.Cut. 2012. Isolasi dan Karakterisasi Bakteri Berpotensi Probiotik pada Ikan Kembung (Rastrelliger sp.). Jurnal Depik, Vol.1, No.3.

Sahara, F.N.I., K.R. Ocky dan S.Endang. 2013. Identifikasi Pigmen Karotenoid Pada Bakteri Simbion Rumput Laut Kappahhycus alvarezii. Journal of Marine Research, Vol. 2, No. 3.

Saputra, S. 2010. Mikroflora Usus. Diakses dari http://www.biologi.lipi.go.id. Pada tanggal 7 April 2015. Pukul 08.15 WITA.

Sari, M.L., A.Arfan, dan Merint. 2013. Isolasi dan Karakterisasi Bakteri Asam Laktat pada Usus Ayam Broiler. Jurnal Agripet, vol.13, no.1.

Suastika, M., S.Fatuchri, dan S.Arif. 2008. Studi Kelayakan; Meningkatkan Pembesaran dan Nutrisi Lobster di Nusa Tenggara Barat. ACIAR-SADI Report.

Subagiyo dan D. Ali. 2011. Skrining Kandidat Bakteri Probiotik dari Saluran Pencernaan Ikan Kerapu Berdasarkan Aktivitas Antibakteri dan Produksi Enzim Proteolitik Ekstraseluler. Jurnal Ilmu Kelautan, Vol. 16, No.1.

Widanarni, D.M., S. Nuryati, Sukenda dan A. Suwanto. 2004. Uji Patogenisitas Vibrio harveyi pada Larva Udang Windu Menggunakan Resisten Rifampisin sebagai Penanda Molekuler. Jurnal Akuakultur Indonesia, Vol.3, No.3.

Yunita, M., H. Yusuf dan Y. Rini. 2015. Analisis Kuantitatif Mikrobiologi pada Makanan Penerbangan (Aerofood ACS) Garuda Indonesia berdasarkan TPC (Total Plate Count) dengan Metode Pour Plate. Jurnal Keteknikan Pertanian Tropis dan Biosistem, vol.3, no.3.

Zaki, I. 2011. Pengaruh Lama Penyimpanan terhadap Kualitas Mikrobiologi Biskuit Bayi dengan Substitusi Tepung Labu Kuning (Cucurbita moschata) dan Tepung Ikan Patin (Pangasius spp) sebagai MP-ASI. Semarang: Universitas Diponegoro. 